\title{
ODWAGA ŚWIADOMOŚCI. O FRANCUSKIEJ RECEPCJI EDYTY STEIN
}

\section{Maritain - neotomistka}

Jeszcze w latach trzydziestych Edyta Stein wkracza we francuski świat intelektualny. Uczestniczy w konferencji fenomenologicznej trwającej od 12 do 14 września 1932 roku w Juvisy. Stein trafia w przestrzeń "towarzystwa tomistycznego", którego wiceprezydentem jest "neotomista” Jacques Maritain. W konferencji uczestniczą między innymi J. Maritain, D. Feuling, A. Koyré, R. Kremer, G. Söhngen, A. Forest. Tematem przedpołudniowych obrad jest fenomenologia, a ściślej zagadnienie fenomenu, idealizm i egzystencjalizm, związek filozofii Husserla z metafizyką i neoscholastyką oraz zagadnienie realizmu, głównie w odniesieniu do prac Husserla i Heideggera. Edyta Stein wyjaśnia rozumienie fenomenu przez Husserla, omawia jego stosunek do metafizyki, objaśnia metodę fenomenologiczną, przeciwstawia dedukcję - ,jawieniu się", fenomenologicznemu oglądowi.

Podczas swojego dziesięciodniowego pobytu we Francji, Stein zwiedza dokładnie Paryż $\dot{1}^{1}$ Spotyka się z Raïssą i Jacquesem Maritainami w ich domu w Meudon - domu organizującym życie intelektualne ówczesnej Francji. Po swoim pobycie zostaje członkiem Komitetu Towarzystwa Tomistycznego.

${ }^{1}$ Stein zwiedza w Paryżu kościóły Saint-Étienne-du-Mont, de la Madelaine, św. Augustyna, bazylikę Sacré-Coeur, Katedrę Notre-Dame, Panteon, Sorbonę, Plac Zgody, Plac Gwiazdy, Plac Wogezów, Plac Vendôme, bulwar świętego Michała, Lasek Buloński, Louvre, Montmartre, podróżuje po Sekwanie i jedzie Saint-Germain-en-Laye i Juvisy. Zob. C. Rastoin, D.-M. Golay, Avec Edith Stein découvrir le Carmel français, Toulouse 2005, s. 9. 
Jeszcze za życia, Stein publikuje dwa teksty w języku francuskim: swoje uwagi wygłoszone podczas konferencji w Juvisy (Stein osobiście sprawdza tłumaczenie francuskie) oraz swoją recenzję dzieł Husserla (Edmund Husserl, la crise de la science et de la philosophie transcendentale: intrduction à la philosophie phénoménologique²).

Spotkanie z Maritainami owocuje przyjaźnią. Niewątpliwie łączy ich ciepła relacja, zarówno intelektualna, jak i duchowa ${ }^{3}$, mimo iż wydarzenia poprzedzające II wojnę światową nie sprzyjały jej rozwojowi. W tle ich rozmów i zażyłości duchowej kształtują się poglądy dotyczące dzieła Tomasza z Akwinu oraz zarysowuje tożsamość żydowska Stein. Natomiast Raïssę Maritain łączy z Edytą Stein żydowskie pochodzenie.

Edyta Stein koresponduje z Maritainami4 ${ }^{4}$. Zachowały się jej cztery listy. Dwa sprzed wstąpienia i dwa po wstąpieniu do Karmelu. Raïssa przesyła jej swoją książkę o św. Tomaszu adresowaną do dzieci. Edyta popiera pomysł przetłumaczenia jej na niemiecki. Książka ukaże się już w 1935 roku w Niemczech. Natomiast Jacques Maritain śle jej swoją rozprawę filozoficzną (Degrés du Savoir) oraz książkę o modlitwie dla intelektualistów (De la vie d'oraison). Jacques Maritain jest przedstawicielem neotomizmu francuskiego, podczas gdy Stein odczytuje myśl Tomasza z Akwinu w świetle fenomenologii5; nie znaczy to jednak, że ich poglądy filozoficzne zdecydowanie się różnią. Edyta wyznaje, że myśli Maritaina były dla niej pomocą przy pisaniu rozprawy Byt skończony a byt wieczny. W wywodach zawartych w szkicu Sens i możliwość "filozofii chrześcijańskiej", zamieszczonym w tym dziele, szeroko komentuje nie tylko pojęcie filozofii czystej i filozofii chrześcijańskiej, ale czyni to w odniesieniu między innymi do poglądów Maritaina ${ }^{6}$. Nie będę przytaczać szczegółowych kwestii związanych z tymi pojęciami, skonstatuję jedynie, że, podobnie jak Maritain, Stein uważa, że filozofia winna zabiegać o teologiczne uzupełnienie, bowiem przy dociekaniu praw-

2 E. Stein, Edmund Husserl, la crise de la science et de la philosophie transcendentale: intrduction à la philosophie phénoménologique, „Revue Thomiste”, t. XLIII, nr 2, lipiec-sierpień 1937, s. 327-329 .

${ }^{3}$ R. Mougel, [Komentarz do listów Edyty Stein do Mariatainów] „Cahiers Jacques Maritain" 1992, nr 25, tytuł Zeszytów: Lettres d'Edith Stein, textes de Raïssa Maritain, red. R. Mougel, s. 31.

4 Tamże.

${ }^{5}$ E. Stein napisała na 70-lecie urodzin E. Husserla tekst Rozmowa św. Tomasza z Akwinu $z$ Edmundem Husserlem (zamieszczony w: Światło rozumu i wiary, tłum. J. Zychowicz, Poznań 2002), w którym zademonstrowała odczytanie fenomenologii w kontekście tomizmu.

${ }^{6}$ Zob. E. Stein, Sens i możliwość "filozofii chrześcijańskiej", w: tejże, Byt skończony a byt wieczny, tłum. J.I. Adamska OCD, Poznań 1995; szczególnie s. 44-56. W kwestiach filozofii chrześcijańskiej Stein odwołuje się też do Gabriela Marcela. 
dy $\mathrm{w}$ świetle naturalnego rozumu nie jest $\mathrm{w}$ stanie uchwycić sensu bytu i istoty człowieka jako osoby obdarzonej duszą i przekraczającej swe zewnętrzne, materialne i zmysłowe uwarunkowania. Stąd nie negując racji rozumowych, Stein postuluje konieczność włączenia teologii w służbę filozofii, nie widząc sprzeczności w zbitce pojęciowej "filozofia chrześcijańska”, a wręcz odwrotnie - dostrzegajac jej nośne poznawczo rozszerzenie na kwestie światopoglądowego i etycznego zarazem uprawiania filozofii, w szczególności fenomenologii, otwarcia filozofii na Transcendencję i perspektywę wieczności. Dla problemu francuskiej recepcji Stein kwestie poruszane na konferencji $\mathrm{w}$ Juvisy mieszczą się zatem $\mathrm{w}$ olbrzymim zagadnieniu recepcji tomizmu w ogóle, w dalszej kolejności dopiero jego powiązań z fenomenologią, a fenomenologii z filozofią chrześcijańską czy teologią. Nie bez znaczenia na tę recepcję pozostaje racjonalistyczna tradycja filozoficzna we Francji, która preferuje tomizm skupiający się na racjach rozumowych $\mathrm{w}$ dowodzeniu istnienia Boga, oddzielając od nich kwestie poznawcze związane $\mathrm{z}$ wiarą. Jak się przekonamy, istotna dla całokształtu tej recepcji będzie też francuska laicka myśl oświeceniowa. To, co zastanawia w naukowej relacji między Stein a Maritainem, to to, że jest ona niesymetryczna. E. Stein odnosi się do myśli Maritaina wielokrotnie i merytorycznie, Maritain nie rewanżuje się jej „naukowym poważaniem” - początkowo zainteresowany fenomenologią, pozostanie raczej wierny myśli Tomasza z Akwinu. Jak przekonuje współczesna badaczka filozofii Maritaina, Marion Duvauchel7, nie ma w jego spuściźnie żadnego odniesienia do dzieł czy myśli Stein. Jest natomiast uwaga o jej ujmującej twarzy - komplement skierowany do bardzo zdolnej uczennicy Husserla. Również dokumenty zgromadzone w archiwum Steinowskim we Francji sugerują, że nasza filozofka na konferencji w Juvisy, poza erudycją i inteligencją, nie wzbudziła poważniejszego zainteresowania, chociaż jej zachowane wypowiedzi poruszają kwestie zasadnicze dla fenomenologii i filozofii w ogóle (pojęcie filozofii czystej, filozofii chrześcijańskiej, fenomenu, kwestia Heideggera, fides i ratio, i inne).

Natomiast Edyta Stein i Raïssa Maritain żyją w głębokiej łączności duchowej. W obliczu tragicznych wydarzeń wojennych obie złożą ofiarę ekspiacyjną Chrystusowi w 1939 roku. O tej komunii dusz relacjonuje „Pamiętnik Raïssy"8.

${ }^{7}$ M. Duvauchel jest autorką artykułów komentujących twórczość J. Maritaina oraz monografii, L'Esthetque oubliée de Jacques Maritain. Un chemin de poésie et de raison, Paris 2009.

${ }^{8}$ J. de Fabrègues, La Conversion d'Edith Stein in Journal de Raïssa, cyt. za: R. Mougel, dz. cyt., s. 33. 
Po wojnie, w latach pięćdziesiątych, Maritainom zostanie przyznana przez Amerykańskie Stowarzyszenie im. Edyty Stein (Edith Stein Guild) nagroda za rozwijanie relacji żydowsko-chrześcijańskich Wtedy to Maritain wyrazi swój podziw dla narodu żydowskiego. To, co wcześniej odnotował w swoich pamiętnikach, teraz powtórzy przy wręczeniu nagrody: 14 września 1932 (dzień podniesienia Krzyża) odwiedziła go i Raïssę, wraz ze swoimi przyjaciółmi, Edyta Stein, z której twarzy emanowały entuzjazm, inteli-

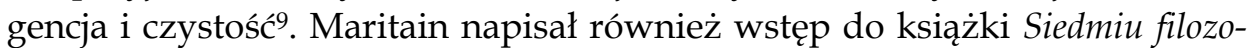
fów żydowskich wobec Chrystusa przedstawiającej Stein jako chrześcijankę pochodzenia żydowskiego ${ }^{10}$. Tak więc mimo całej sympatii, jaką Jacques Maritain darzył Edytę Stein, w swoich wspomnieniach, notatkach i listach nie zawarł merytorycznych odniesień do jej prac naukowych, do jej myśli filozoficznych. Skupiał się głównie na osobie i życiu Edyty Stein.

Początkowo recepcja Stein we Francji odbywa się poprzez jej relację z Maritainami, dlatego też widzi się w niej błyskotliwą uczennicę Husserla11, żydówkę i osobę obdarzoną siłą oddziaływania. Inny francuski szlak recepcji dzieła Stein wyznaczą jej duchowe zainteresowania.

\section{Dialogi Karmelitanek z Compiègne}

Edyta Stein zna język francuski na tyle, żeby w nim czytać i z niego tłumaczyć. Zachowa jednak pewną ostrożność w czasie wspomnianej konferencji tomistycznej i wygłosi swe kwestie w języku niemieckim; większość listów też pisze po niemiecku. Znajomością języka wykaże się, będąc już we wspólnocie karmelitańskiej12. Prowadzi wtedy korespondencję już po francusku. Ale nie tylko. Śledzi między innymi francuską duchowość karmelitańską poprzez losy sióstr karmelitanek i osób świeckich związanych z duchowością Karmelu. Bliskie są jej Madame Acarie, siostry Marie-Aimée de Jésus, Maria Antonina de Geuser, Elżbieta od Trójcy Świętej, Maria od Jezusa Ukrzyżowanego (Mała Arabka), Teresa z Lisieux. Szczególną jej uwagę przyciągną karmelitanki z Compiègne, które zostały zgilotynowane w Paryżu w czasie Rewolucji Francuskiej podczas religijnych

\footnotetext{
9 Tamże.

${ }^{10} \mathrm{P}$. Oesterreicher, Walls are Crumbling (fr. Sept philosophes juifs devant le Christ), cyt. za: R. Mougel, dz. cyt., s. 33.

${ }^{11} \mathrm{~F}$. Lavigne, Edith Stein n'a jamais cessé d'être philosophe, www.la-croix.com/Culture/ Livres-Idees/Livres/Edith-Stein-n-a-jamais-cesse-d-etre-philosophe-2013-04-15-942854 [dostęp: 20.02.2014].

${ }^{12}$ C. Rastoin, D.-M. Golay, dz. cyt., s. 125-142.
} 
prześladowań 17 lipca 1794 roku. Szesnaście karmelitanek oddało swoje życie Chrystusowi i zginęło za kraj, prosząc Boga, by uśmierzył swój gniew względem Francji. Zainteresowanie Stein historią sióstr z Compiègne przyczyni się pośrednio do napisania przez Bernanosa sztuki Dialogi Karmelitańskie (1949). To nie Stein przedstawia Bernanosowi historii karmelitanek, lecz czyni to via Gertruda von Le Fort. Zna ją bowiem osobiście, z nią omawia szczegóły noweli Ostatnia na szafocie. Obie spotykają się w Monachium i w Kolonii w 1934 roku, żeby dyskutować o duchowości karmelitańskiej. Natomiast Bernanos był zachęcony do napisania Dialogów Karmelitańskich przez ks. Raymonda Bruckbergera i Philippa Agostini. W przypadku Bernanosa, chodziło o filmową adaptację noweli von Le Fort przez Raymonda Bruckbergera ${ }^{13}$.

Nowela Gertrudy von Le Fort, napisana w latach trzydziestych, była manifestem i reakcją na nasilający się $\mathrm{w}$ Republice Weimarskiej nazizm ${ }^{14}$. Francuskie wydarzenia okresu Terroru mają być zatem pretekstem do zdemaskowania poczynań partii NSDAP i Hitlera, które coraz częściej wzbudzają powszechny i społeczny lęk poprzez, między innymi, nasilenie przemocy. Początek lat trzydziestych jest również dla Stein czasem próby. Trasę do Kolegium Marianum w Münster przebywa, mijając nazistowskich studentów. Niedługo później traci pracę. 7 maja 1933 roku, według relacji C. Rastoin, pisze do jednej ze swoich uczennic: „Myślę, że gdybyś wiedziała więcej o tym, ilu ludzi pogrąża się w rozpaczy, tęskniłabyś raczej do tego, aby im odjać trochę z nadmiaru ich bied i cierpienia"15. Stein rozeznaje również powołanie Kościoła do modlitwy ukrytej. $Z$ tej perskeptywy nawiązuje też do nieujawnionej historii dziejów. Odwołuje się tym samym do Teresy z Ávila i jej podopiecznych sióstr, jak i do samej historii Hiszpanii, która w odróżnieniu od Francji, Królestwa Niderlandów i Prus, została uchroniona od podziałów religijnych. Kiedy w latach trzydziestych nienawiść opanowuje i dzieli Niemców, Stein upatruje ostatnią nadzieję zbawienia w ukrytej działalności, w ukrytym źródle, którym jest modlitwa ${ }^{16}$, oraz w cierpieniu ekspiacyjnym, "zarezerwowanym” dla osób dostrzegających nadnaturalne zależności wydarzeń w historii i dziejach świata ${ }^{17}$.

${ }_{13}$ C. Rastoin, Edith Stein (1891-1942). Enquête sur la Source, Paris 2010, s. 127. Zob. dwa rozdziały: Hedwig et la vérité de Thérèse, s. 129-138 i Vie d'une famille carmélitaine, s. 233-243.

14 Tamże, s. 130.

${ }^{15}$ E. Stein, Autoportret z listów, cz. 1: 1916-1933, tłum. J.I. Adamska OCD, A. Talarek, Kraków 2003, s. 403. Zdanie przytoczone przez C. Rastoin w: Avec Edith Stein découvrir le Carmel français, dz. cyt., s. 133.

${ }^{16}$ C. Rastoin, D.-M. Golay, dz. cyt., s. 133. C. Rastoin odsyła do dzieł zebranych E. Stein: Source cachée, oeuvres spirituelles, Paris-Genève 1988 (II wydanie: 1999), s. 69.

${ }_{17}$ C. Rastoin, D.-M. Golay, dz. cyt., s. 137, E. Stein, Source cachée, dz. cyt., s. 233. 
To właśnie C. Rastoin - współczesna badaczka spuścizny Stein, a zarazem karmelitanka - dostrzega zależności pomiędzy modlitwą ukrytą i ofiarą ekspiacyjną karmelitanek z Compiègne i Edyty Stein, między rewolucyjnym okresem Terroru we Francji i nazizmem III Rzeszy ${ }^{18}$. Siostrę Benedyktę od Krzyża - według niej - łączy z Karmelem francuskim ofiara życia, która jest jednocześnie błaganiem o łaskę dla kraju w okresie trudnej, uwikłanej, walczącej z Kościołem, historii.

\section{Edyta Stein a Karmel francuski}

Stać przed obliczem Boga - to powołanie proroka Eliasza, to również karmelitańskie powołanie ${ }^{19}$, polegające na trwaniu przed Panem w „Kościele Ukrytym”. Karmel nie jest dla Edyty alienującą twierdzą, ale staje się miejscem dialogu między katolikami i Żydami. Karmelitańskim powołaniem Stein jest wydobycie żydowskich korzeni zgromadzenia. Święta Benedykta od Krzyża dzięki swojemu nawróceniu i żydowskiemu pochodzeniu wskazuje na tradycję karmelitańską, która swój biblijny początek upatruje w Księdze Królewskiej, a posłannictwo Karmelu w postawie proroka Eliasza. Eliasz trwa przed Obliczem Boga ${ }^{20}$. Jako Żydówka, jest ona również darem dla kościoła powszechnego i katolickiego. Wskazuje na źródło, korzeń i początek biblijnego przymierza i chrystusowego zbawienia. Stein przychodzi na świat w święto Jom Kippur, w żydowski Dzień Pojednania. Nazywając siebie Ester, utożsamia się tym samym z narodem wybranym i oddaje $\mathrm{w}$ ręce Achaszwerosza tamtych czasów. Z tego punktu widzenia, Stein odnawia kult żydowski w Karmelu, jak również stanowi pomost $\mathrm{w}$ dialogu między judaizmem i chrześcijaństwem ${ }^{21}$.

\section{Edyta Stein a filozofia}

Niewątpliwie do ożywienia rozważań nad myślą Edyty Stein przyczyniła się we Francji jej beatyfikacja i kanonizacja. Te dwa wielkie wydarzenia dadzą zaczyn konferencjom i pracom na temat dzieł i życia Edyty Stein.

${ }^{18}$ C. Rastoin, D.-M. Golay, dz. cyt., s. 137.

${ }^{19}$ C. Rastoin, Edith Stein, dz. cyt., s. 262.

20 Tekst E. Stein jest cytowany przez C. Rastoin w: Edith Stein, dz. cyt., s. 262-263.

${ }^{21}$ Pogląd podobny do stanowiska Rastoin wyraża Roman Weksler-Waszkinel w tekście Aby dać szansę nadziei, "Zeszyty Naukowe CBES” 2005, nr 1. 
W latach trzydziestych wizerunek Stein ogranicza się jedynie do roli asystentki Husserla. Zaraz po wojnie widzi się w niej przede wszystkim odważną świętą i męczennicę. Jej życie przedstawione w perspektywie krzyża zdaje się po dzień dzisiejszy schematem wiodącym we francuskiej recepcji Stein ${ }^{22}$. Przypomnijmy, że Maritain pisze wstęp do książki Siedmiu filozofów zydowskich wobec Chrystusa. Natomiast do lat siedemdziesiątych ukazał się jedynie przekład dwóch dzieł Stein: Kobieta. Jej zadanie wedtug natury $i$ łaski (w roku 1956) oraz Wiedza Krzyża. Studium o św. Janie od Krzyża (w roku 1957). W latach siedemdziesiątych i osiemdziesiątych punkt ciężkości przesuwa się w stronę fenomenologii, zostają sukcesywnie przełożone dzieła Byt skończony, a byt wieczny (w roku 1972) oraz Światopogladowe znaczenie fenomenologii (w roku 1987).

Pozycja Stein i miejsce jej myśli w humanistyce francuskiej są jednak nadal problematyczne. Św. Teresa $z$ trudem wywalcza sobie w niej obecność. Obowiązująca tu zasada laickości z pewnością wytwarza opór w przyjęciu dzieł Stein we Francji. Sekularyzm bowiem przenika dogłębnie filozoficzno-polityczno-społeczną myśl francuską. W szkołach publicznych Republiki Francuskiej istnieje - jak wiemy - zakaz obnoszenia się z symbolami religijnymi, a przekonania religijne nie powinny wykraczać poza sferę prywatną. $\mathrm{Z}$ tego też powodu podejmowanie problematyki teologicznej i zagadnień z zakresu filozofii chrześcijańskiej, a także studia nad świętymi-filozofami mogą wydać się raczej kłopotliwe. Zdaniem Jean-François Lavigne'a ${ }^{23}$, autora książek na temat fenomenologii Husserla, myśl naukowa i droga chrześcijańska Stein zostały spontanicznie przyjęte w Niemczech, we Włoszech, w świecie anglosaskim, ale nie we Francji, gdzie panuje przeświadczenie o konieczności rozdzielenia przekonań religijnych i racjonalnej myśli filozoficznej. Ponadto, dzieła Stein przez długi okres nie były tu ani tłumaczone, ani wydawane. Francuski świat filozoficzny przez lata nie mógł zapoznać się i skonfrontować z jej myślą.

\section{Wydawnictwo}

Jednak to nie tylko francuska laickość jednoznacznie wpłynęła na opóźnienie w wydawaniu dzieł Stein. Problem związany był z udzieleniem wyłącznych praw autorskich do jej dzieł szwajcarskiemu wydawnictwu Ad Solem, które przez długi okres zaniechało ich publikowania. Dopie-

${ }_{22}$ É. de Miribel, Ch. Chabanis, I.-H. Marrou, Comme l'or purifié par le feu : Édith Stein, 1891-1942, Paris 1984; J. Bouflet, Édith Stein philosophe crucifiée, Paris 1998.

${ }^{23}$ F. Lavigne, dz. cyt. 
ro $\mathrm{w}$ ostatnim okresie we współpracy z wydawnictwem Karmelitańskim Éditions du Carmel i wydawnictwem Cerf opublikowano Korespondencje Edyty (dwa wydania: 2009 i 2012), Życie pewnej żydowskiej rodziny (w roku 2008) i O zagadnieniu wczucia (w roku 2013).

\section{Edyta Stein dzisiaj}

Obecnie Edyta Stein wzbudza coraz większe zainteresowanie. Wspomniany J.-F. Lavigne sugeruje, że nastał czas, aby nowe pokolenie odkryło obecną w jej życiu „głęboką jedność między świadomością filozoficzną i świadomością religijną"24. Niewątpliwie do rozpowszechniania jej myśli przyczyniła i przyczyni się przywołana już wielokrotnie C. Rastoin, przeorysza Karmelu na Montmartre. Rastoin przetłumaczyła większość dzieł Edyty na język francuski, a także napisała kilka poświęconych jej dzieł krytycznych: Édith Stein et le mystère d'Israël (Ad Solem, 1998); Edith Stein (1891-1942). Enquête sur la source (Éd. du Cerf, 2007); Avec Édith Stein découvrir le Carmel français (z D.-M. Golay; Éd. du Carmel, 2005).

Myśl Edyty Stein rozpowszechnia również Instytut św. Jana od Krzyża działający przy Karmelu w Tuluzie, tam też organizowane są konferencje i seminaria dotyczące jej myśli (Mystère chrétien et expérience spirituelle chez Jean de la Croix et Edith Stein, cykl 4 konfrencji, Tuluza 2000; Międzynarodowa konferencja E. Stein, Tuluza 2005; Introduction à l'anthropologie philosophique et théologique avec Edith Stein; Le problème de l'empathie selon Edith Stein - konferencje, które miały miejsce podczas uniwersytetu letniego, Tuluza 2013). We wrześniu 1998 roku École Cathédrale w Paryżu zorganizowało konferencję poświęconą Edycie Stein przy okazji jej kanonizacji. Jej myśl konfrontuje się coraz częściej w przestrzeniach instytucji świeckich. Konferencje na temat jej twórczości zorganizowały wspólnie w kwietniu 2013 Collegium Bernardinum, École Normale Superieure oraz Centrum studiów Saulchoir. Wydaje się coraz więcej książek na jej temat oraz na temat jej twórczości. Na planie filozofii nieustannie powraca temat osoby ludzkiej i wspólnoty (V. Aucante, De la solidarité. Essai sur la philosophie politique d'Édith Stein, Parole et Silence, Paryż 2006); formacji człowieka (E. de Rus, L'art d'éduquer selon Édith Stein. Anthropologie, éducation et vie spirituelle, Cerf-Ad-Solem-Carmel, Genewa - Paryż - Tuluza 2008; E. de Rus, Intériorité de la personne et éducation chez Édith Stein, Cerf, Paryż 2006), ale też temat kobiety (S. Binggeli, Le féminisme

24 Tamże. 
chez Edith Stein, Paroles et silence, Paryż 2009; S. Courtine-Denamy, Les trois femmes dans de sombres temps, Hachette, Paryż 2004, polski tytuł: Trzy kobiety $w$ dobie ciemności, tłum. G. Przewłocki, Świat Książki, Warszawa 2012).

\section{Wielokulturowość}

Bez wątpienia życie i twórczość Stein niosą odpowiedzi na dzisiejsze pytania naszej cywilizacji. Według Oliviera de Berranger, emerytowanego biskupa Saint-Denis, Stein przychodzi na pomoc społeczeństwu wielokulturowemu i wielowyznaniowemu, społeczeństwu zlaicyzowanemu.

Stein, będąc Żydówką, nie mieści się do końca w tożsamości żydowskiej, ale jednocześnie się do niej odważnie przyznaje ${ }^{25}$. Żyje w Niemczech, jest całkowicie zasymilowana, w pełni wpisuje się w swoją epokę. Można by powiedzieć, że poniekąd jest "na czasie”, jest nowoczesna, a w latach trzydziestych XX wieku - latach dopiero co rodzącej się emancypacji - jest kobietą niezależną, zdobywającą tytuły naukowe, głoszącą wykłady na konferencjach, udzielającą się publicznie. A jednak jej wysoko rozwinięta świadomość społeczna jest boleśnie naznaczona. Jej pozycja jest niewygodna. Wielokulturowa świadomość stawia ją w trudnej sytuacji. W planie żydowskiej rodziny nie spotyka się ze zrozumieniem, jej nawrócenie poczytywane jest częstokroć za zdradę (apostazję). Natomiast w Kościele katolickim i w Karmelu boli ją niedelikatność sądów niektórych sióstr, brak jasnego stanowiska Kościoła katolickiego w kwestii żydowskiej w czasie II wojny światowej. Niewątpliwie Edyta zna i rozumie różne przestrzenie ludzkiej egzystencji. Jej świadomość pogłębiona jest tym bardziej, że porusza się i żyje w wielu obszarach kulturowych, a jej tożsamość jest wielokulturowa.

W liście do papieża Piusa XI Edyta Stein pisze w imieniu Niemców, sama uważając się za Żydówkę i katoliczkę. „Ojcze Święty! Jako dziecko narodu żydowskiego, które przez łaskę Boga od jedenastu lat jest dzieckiem Kościoła Katolickiego, ośmielam się wyrazić przed Ojcem chrześcijaństwa to, co boli miliony Niemców"26. Odwaga Stein polega na tym, że nie ucieka ona od swojego trudnego położenia i ze swej trudnej pozycji broni praw i prawdy. Stein pisze do papieża w imieniu Niemców i Żydów, ale też w imię ra-

25 S. Courtine-Denamy, Trois femmes dans de sombres temps, Édith Stein, Hannah Arendt, Simone Weil ou amor fati, amor mundi, Paris 2002, s. 83.

${ }^{26}$ Edyta Stein, List do Papieża, tłum. M. Zając, „Tygodnik Powszechny”, nr 92.03.2003 r. 
towania twarzy i wiarygodności katolików. Jej żydowska świadomość jest również świadomością historii. Jako Żydówka żyje w nazistowskich Niemczech, jako katoliczka umiera za naród żydowski.

\section{Dialog we Francji}

Stein poprzez fenomenologiczne badania na temat wczucia, poprzez kulturę przebaczenia i pojednania i przede wszystkim poprzez postawę życia wskazuje na dialog, dialog trudny, naznaczony historią i cierpieniem. Już za życia, Stein realnie angażuje się w dialog katolickoprotestancki ${ }^{27}$. Dlatego też obecność Stein we Francji wydaje się szczególnie ważna. Spory religijne zostawiły trwałe ślady we francuskim myśleniu i postawie. Stłumienie katarskiej herezji, ustalenie siedziby papiestwa w Awinionie, trzydziestoletnie wojny religijne wieku XVI, krwawa noc św. Bartłomieja (24 sierpnia 1572 roku), uwikłania katolicyzmu i protestantyzmu we władzę, konfiskacja dóbr kościelnych i skazanie na śmierć duchownych niechcących poddać się władzy w czasie Rewolucji Francuskiej - wszystkie te zdarzenia są nadal żywe w świadomości społecznej Francuzów. Nie bez przyczyny Francja jest szczególnie wrażliwa na konflikty religijne, a laickość widnieje na głównym miejscu w jej konstytucji. Taki stan rzeczy rodzi silną polaryzację postaw - od dystansu wobec religii do skrajnego zaangażowania. Ponadto Francja jest społeczeństwem wielokulturowym, wieloreligijnym. Stein niewątpliwie uczy, przez zagadnienie "wczucia” i swoją tożsamość, obcowania $w$ społeczeństwie wielokulturowym ${ }^{28}$. Niektórzy badacze uważają, że wczucie oraz filozofia dialogu mają swoje źródło w żydowskości Stein ${ }^{29}$. Biskup Olivier de Berranger we wstępie do Dziejów pewnej żydowskiej rodziny zauważa, iż Stein przypomina ludziom starego kontynentu o szacunku i tolerancji, o gościnności, zaprasza mężczyzn i kobiety do tego, by się rozumieć i zaakcaptować ponad różnicami rasowymi, kulturowymi i religijnymi. Berranger postuluje, za Janem Pawłem II, aby tworzyć społeczeństwo braterskie, a Stein - jak wiemy - uczy, jak w nim żyć (chociażby w tekście Indywidualność a wspólnota). Z tego punktu widzenia pełni ona spo-

${ }_{27}$ Feuille épiscopale de Spire, in Le Pèlerin, no 30, 27 juillet 1930, s. 699, 700, repris par EWS Tome XII, s. 123-125.

${ }_{28}$ Por. J. Nota, Edyta Stein a projekt encykliki przeciwko rasizmowi $i$ antysemityzmowi, tłum. J. Zychowicz, "Znak-Idee”: Edyta Stein albo filozofia i krzyż, red. P. Taranczewski, K. Tarnowski, H. Woźniakowski, Kraków 1989, s. 65-79; A. Grzegorczyk, Ponad kulturami. Uniwersalizm Edyty Stein, Poznań 2010, s. 150.

${ }^{29}$ Zob. J. Dujardin, L'Église catholique et le peuple juif, un autre regard, Paris 2003. 
łeczną misję. Sam jej testament i śmierć przypominają śmierć karmelitanek z Compiègne. Ofiara życia karmelitanek z Campiègne oraz ofiara życia Stein za kraj, naród, wspólnotę wskazują na wyższą świadomość życia społecznego. Stein, mając pustelnicze powołanie, ofiaruje się za wspólnotę, żyje dla wspólnoty Kościoła. Czy to nie zastanawiające, że Bernanos pisze swoją sztukę Dialogi Karmelitańskie po wojnie, kiedy świat jest spragniony relacji i wspólnotowości ponad nacjonalizmami? Testament Stein włącza się $\mathrm{w}$ testament karmelitanek z Compiègne:

Już dziś z radością przyjmuję śmierć, jaką mi przeznaczył Bóg, posłuszna Jego świętej woli. Proszę Pana, aby moje życie i śmierć przyjął ku swojej chwale i uwielbieniu, za wszystkie prośby Najświętszego serca Jezusowego, Maryi i Kościoła Świętego, szczególnie za utrzymanie i doskonałość naszego świętego Zakonu - a mianowicie za Karmel z Kolonii i Echt, jako pokutę za niewiarę narodu żydowskiego [...], na ratunek Niemiec i pokoju na świecie, ofiaruję także za moich krewnych, żyjących i zmarłych, i za wszystkich, których dał mi Bóg: aby nikt nie został potępiony ${ }^{30}$.

\section{Konkluzje}

Dzieła Edyty Stein zostały we Francji stosunkowo późno przetłumaczone. W ostatnich latach daje się dostrzec jednak zasadniczą zmianę $\mathrm{w}$ ich recepcji: ukazują się krytycznie zredagowane przekłady jej dorobku oraz rzetelne omówienia jej dzieł. Tematy opracowań myśli Stein są ściśle związane z jej twórczością, obejmują zatem wizję kobiety, judaizmu, pedagogiki, fenomenologii oraz zagadnienie wczucia. Ta problematyka podejmowana jest - jak sadzę - z uwagi na uniwersalne treści, które zawiera. Trudno jednoznacznie uchwycić jej wpływ na francuską humanistykę lub uogólnić jej przyjęcie w rozległej przestrzeni duchowej i intelektualnej. Jednak próba interpretacji komentarzy jej dzieł naprowadza na francuską specyfikę recepcji jej myśli. Ta recepcja przechodzi nadal pewnego rodzaju ewolucję. Od fenomenolożki i neotomistki, poprzez świętą karmelitańską, Edyta staje się patronką nie tylko Europy, ale i życia w społeczeństwie wielokulturowym i wielowyznaniowym i z trudem, ale jednak, dociera do kręgów filozoficznych. I choć francuska myśl intelektualna jest silnie osadzona w paradygmacie oświeceniowym, w paradygmacie rozszczepienia filozofii i wiary, $\mathrm{w}$ dziele Stein upatruje się pomocy w przekroczeniu istniejącego dualizmu. Można zatem przypisać szczególną pozycję Stein we Francji, opierając się na następujących uogólnieniach:

\footnotetext{
${ }^{30}$ Cyt. Za: A. Grzegorczyk, dz. cyt., s. 154.
} 
1. Jej myśl filozoficzna zostaje we Francji wprowadzona późno z uwagi na rozpowszechnioną laicką formę myślenia, oddzielającą filozofię i wiarę (F. Lavigne).

2. Jako fenomenolog, Stein wskazuje na możliwość przezwyciężenia wciąż żywych we Francji idei Oświecenia, takich jak skrajny racjonalizm, relatywizm, historycyzm i sceptycyzm (F. Lavigne).

3. Stein, zarówno w Kościele powszechnym, w Kościele francuskim, jak i w Karmelu, jest świadkiem żydowskiego życia (stanowisko J. Maritaina, C. Rastoin i M. Dubois); jednocześnie jej życie i twórczość są zachętą, aby po raz kolejny wrócić do judaistycznych korzeni chrześcijaństwa i zaczerpnąć z ich źródła.

4. Stein staje się w laickiej Francji patronką życia w społeczeństwie wielokulturowym i wielowyznaniowym (O. de Berranger).

5. Silna tożsamość Edyty, jej autentyczność i odwaga, doprowadzą ją do rozwinięcia dialogu z innymi i ostatecznie oddania swojego życia, niczym karmelitanki z Compiègne, z miłości do człowieka i wspólnoty, mimo uwikłanej w ateizm historii (C. Rastoin).

Albert Camus zatytułował zbiór myśli Simone Weil Świadomość nadprzyrodzona z uwagi na jej odnoszenie się do stanu duszy człowieka oświeconego łaską. Myśl Edyty Stein spowija świadomość pogłębiona i trudna. Stein odczytuje i pojmuje świat z poziomu wielu kultur. Ta niewygodna, zakorzeniona $\mathrm{w}$ wielu wymiarach świadomość chroni ją przed relatywizującymi wpływami i prowadzi, poprzez wczucie, do najgłębszych źródeł poznania Transcendencji i innego.

\section{The Courage of the Consciousness. The French Reception of Edith Stein}

Summary

In the 1930s, Edith Steinattends a phenomenological conference in Juvisy (where she meets Jacques Maritain), therebyentering the French intellectual world. Stein knows French: she is interested in the Carmel in France, including the Carmelites of Compiegne, whom remind her of the death of expiatory sacrifice.

And yet the position of Stein and her ideas in the French humanistics is problematic. The current principle of secularism certainly constitutes a resistance to the adoption of Stein's works in France. Moreover, for a long time Stein's works were neither translated nor published and as consequence the French philosophical world for years could not read and confront her thoughts. The reception of her works has been recently changing. Perhaps Stein, being a Jew and a German woman, aids a multireligious, multicultural and secularised society. 